\title{
LESSONS LEARNED: NEEDS FOR IMPROVING HUMAN HEALTH RISK ASSESSMENT AT USDOE SITES
}

\author{
L.D. Hamilton, S. Holtzman, A.F. Meinhold, S.C. Morris, M.D. Rowe \\ Biomedical and Environmental Assessment Group \\ Department of Applied Science \\ Brookhaven National Laboratory \\ Upton, NY 11973
}

J.I. Daniels, D.W. Layton, and L.R. Anspaugh

Health and Ecological Assessment Division

Geosciences and Environmental Research Program

Physics Department

Lawrence Livermore National Laboratory

Livermore, CA 94551-9900

September 1993

Prepared for:

Office of Environmental Restoration and Waste Management

Office of Technology Development

United States Department of Energy

Work performed under the auspices of the U.S. Departunent of Energy by Brooktaven National Laboratory under Contract No. DE-AC02-76CH00016 and by Lawrence Livermore National Labcratory under Contract No. W-7405-Eng-48 


\section{ACKNOWLEDGMENT}

This study was funded by the United States Department of Energy, Office of Environmental Restoration and Waste Management, Office of Technology Development. The Project Officer for the study was Mr. Michael Barainca. This study was a collaborative effort between the Biomedical and Environmental Assessment Group, Brookhaven National Laboratory (BNL) and the Health and Ecological Assessment Division, Lawrence Livermore National Laboratory (LLNL). The principal investigator for the BNL work was Dr. L. D. Hamilton. The principal investigators for the LLNL work were Dr. L.R. Anspaugh and Dr. D.W. Layton. We thank the staffs of the Westinghouse Savannah River Company, Westinghouse Company of Ohio, and the contracting organizations at the Nevada Test Site (NTS), as well as the U.S. Department of Energy (USDOE) personnel associated with the Savannah River Site (SRS), Fernald Environmental Management Project (FEMP), and the NTS for their cooperation. The authors also thank Mr. Leo Duffy and Dr. Clyde Frank at USDOE headquarters in Washington, DC, for their encouragement and support 


\section{DISCLAIMER}

This report was prepared as an account of work sponsored by an agency of the United States Government. Neither the United States Government, no any agency thereof, nor any of their employees, nor any of their contractors, subcontractors or their employees, makes any warranty, express or implied, or assumes any legal liability or responsibility for the completeness or usefulness of any information, apparatus, product or process disclosed, or represents that its use would not infringe on privately owned rights. Reference berein to any specific commercial product, process, or service by trade name, trademark, manufacturet or otherwise, does not necessarily constitute or imply its endorsement, recommendation, or favoring by the United States Government or any agency, contractor or subcontractor thereof. The views and opinions of authors expressed herein do not necessarily state or reflect those of the United States Govemment or any agency, contractor or subcontractor thereof. 


\begin{abstract}
Realistic health risk assessments were performed in a pilot study of three U.S. Department of Energy (USDOE) sites. These assessments, covering a broad spectrum of data and methods, were used to identify needs for improving future health risk assessments at USDOE sites. Topics receiving specific recommendations for additional research include: choice of distributions for Monte Carlo simulation; estimation of risk reduction; analysis of the U.S. Department of Agriculture Database on food and nutrient intakes; investigations on effects of food processing on contaminant levels; background food and environmental concentrations of contaminants; method for handling exposu' 2 s to groundwater plumes: methods for analyzing less than lifetime exposure to carcinogens; and improvement of bioaccumulation factors.
\end{abstract}




\section{Table of Contents}

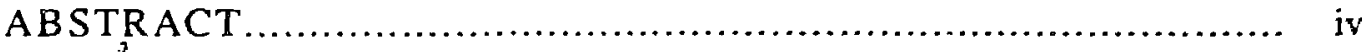

Table of Contents.......................................................... v

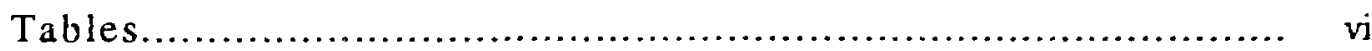

ACRONYMS, ABBREVIATIONS AND SYMBOLS.......................... vii

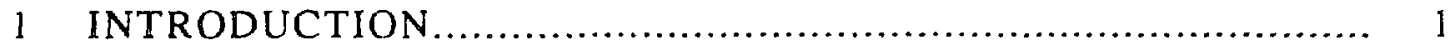

2 REALISTIC RISK ASSESSMENT........................................ 2

2.1 Pilot Siudy Approach to Realistic Risk Assessment for USDOE

2.2 Steps in the Analysis............................................... 2

2.3 Methods and Assumptions.......................................... 3

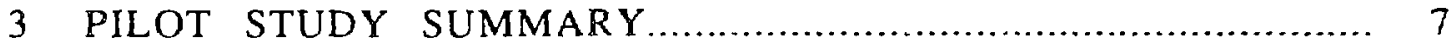

3.1 Introduction.................................................... 7

3.2 Savannah River Site Risk Assessments.............................. 8

3.3 Fernald Environmental Management Project Risk Assessments.......... 9

3.4 Nevada Test Site Risk Assessments..........................................

4 LESSONS LEARNED: INFORMATION AND METHODS NEEDED FOR IMPROVEMENT OF RISK ASSESSMENT AT USDOE FACILITIES.......... 12

4.1 Probabilistic Methods..................................................... 12

4.2 Land-Use Scenarios and Receptors.................................... 13

4.3 Site and Source-Term Characterization.................................... 14

4.4 Transport Models and Physical Parameters................................ 15

4.5 Exposure Calculations............................................. 17

4.6 Dose-Response Relationships......................................... 20

5 SPECIFIC RESEARCH RECOMMENDATIONS............................. 21

5.1 Risk Assessment Methodology...................................... 21

5.2 Estimation of Risk Reduction........................................... 22

5.3 Analysis of USDA Database .......................................... 22

5.4 Effects of Food Processing on Contaminant Levels........................ 22

5.5 Background Food and Environmental Concentrations..................... 23

5.6 Method for Handling Exposure to Groundwater Plumes.................... 24

5.7 Less Than Lifetime Exposuse to Carcinogens................................ 24

5.8 Improvement of Estimates of Biotransfer Factors........................... 25

5.9 Factors Affecting Frequency and Duration of Exposure..................... 25

5.10 Risk Characterization for Plutonium and Noble Gases................... 26

6 SUMMARY AND CONCLUSIONS........................................... 26

7 REFERENCES ........................................................... 27 


\section{Tables}

1. Selected Comparisons of Parameter Values............................................ 5

2. Scenarios and Receptors in the Pilot Study........................................ 7

3. Environmental Transport in the Pilot Study Assessments............................ 8

4. Major Exposure Pathways in the Pilot Study Assessments............................ 8 


\section{ACRONYMS, ABBREVIATIONS AND SYMBOLS}

Term Definition

$\begin{array}{ll}\text { ALI } & \text { Allowable Limit on Intake } \\ \text { BEAG } & \text { Biomedical and Environmental Assessment Group } \\ \text { BEIR } & \text { Committee on the Biological Effects of Ionizing Radiation } \\ \text { BNL } & \text { Brookhaven National Laboratory } \\ \text { Bq } & \text { becquerel } \\ \text { Ci } & \text { Curie } \\ \text { CL } & \text { confidence limit } \\ 137 \text { Cs } & \text { cesium 137 } \\ \text { FEMP } & \text { Fernald Environmental Management Project } \\ \text { HEAD } & \text { Health and Ecological Assessment Division } \\ \text { ICRP } & \text { International Commission on Radiological Protection } \\ \text { K } & \text { distribution coefficient } \\ \text { LLNL } & \text { Lawrence Livermore National Laboratory } \\ \text { LOAEL } & \text { Lowest Observed Adverse Effect Level } \\ \mu & \text { micro, 10 } \\ \text {-6 } & \text { milli, 10-3 } \\ \text { m } & \text { National Council on Radiological Protection and Measurements } \\ \text { NCRP } & \text { No Observed Adverse Effect Level } \\ \text { NOAEL } & \text { Nevada Test Site } \\ \text { NTS } & \text { pico, 10 } 12 \\ \text { p } & \text { picocurie } \\ \text { pCi } & \text { Remedial Investigation/Feasibility Study } \\ \text { RIFS } & \text { radon } \\ \text { Rn } & \text { Savannah River Site } \\ \text { SRS } & \text { Sievert } \\ \text { Sv } & \text { United States Department of Agriculture } \\ \text { USDA } & \text { United States Department of Energy } \\ \text { USDOE } & \text { United States Environmental Protection Agency } \\ \text { USEPA } & \text { Westinghouse Materials Company of Ohio } \\ \text { USNRC } & \\ \text { WMCO } & \text { Snited States Nuclear Regulatory Commion } \\ & \end{array}$




\section{INTRODUCTION}

Decisions about cleanups of environmental contamination at United States Department of Energy (USDOE) facilities should be based on state-of-the-science approaches to human health and ecological risk assessment.

A pilot study to develop methods and demonstrate the feasibility and usefulness of comprehensive and realistic risk assessments for environmental problems at USDOE facilities was completed recently. This study assessed health risks for potential problems at three USDOE facilities: (1) the Savannah River Site (SRS), near Aiken, South Carolina; (2) the Fernald Environmental Management Project (FEMP) in Fernaid, Ohio; and (3) the Nevada Test Site (NTS), near Las Vegas, Nevada. The pilot study was a collaborative effort between the Biomedical and Environmental Assessment Group (BEAG) of Brookhaven National Laboratory (BNL) and the Health and Ecological Assessment Division (HEAD) of Lawrence Livermore National Laboratory (LLNL). These assessments showed that realistic and objective risk estimates can be developed from available information and that such assessments produce results that differ dramatically from estimates produced by approaches that are less careful and thorough.

We define a realistic and objective risk assessment to be one that:

(1) avoids unrealistic and conservative exposure scenarios by focusing on the development of reasonable and sensible scenarios;

(2) replaces generic or inappropriate default assumptions with site-specific data;

(3) explicitly characterizes uncertainties in parameters, and does not depend exclusively on conservative assumptions;

(4) uses site-specific transport and exposure models, and depends on available monitoring data for model calibration or input parameters;

(5) uses the latest scientific information in describing dose-response relationships;

(6) acknowledges that without additional data collection, situations with very litule data available to describe source terms or exposure routes cannot be assessed in the same realistic way, but practically such situations can be addressed credibly using a scientifically defensible risk-based screening analysis.

The individual risk assessments are presented in detail in Hamilton et al., 1993a for the SRS, in Hamilton et al., 1993b for the FEMP, and in Layton et al. 1993 and Daniels et al. 1993 for the NTS.

In addition to the intrinsic value of the risk assessments made in the pilot study, there are specific lessons to be learned from the study. Major uncertainties in data at USDOE facilities are often used to justify reliance on worst-case scenarios and conservative parameter values in assessments. This document uses the experience gained in the pilot study to identify gaps in data and methods for risk assessment at USDOE facilities. Identification of these gaps should help focus effort on research that supports realistic stateof-the-science risk assessments at USDOE sites, and promote the use of ranges of parameter values and corresponding distributions as an improvement over the use of worstcase scenarios and parameter values.

Section 2 of this document outlines the method of realistic and objective risk assessment developed and demonstrated in the pilot study. Section 3 summarizes the results of the risk assessments performed for the SRS, FEMP and NJTS. Section 4 draws from pilot study experience to identify the major gaps in data and describe methods in risk assessment at USDOE facilities, and Section 5 gives specific recommendations for research 
efforts derived from these "lessons leamed" that could improve immediately and directly risk assessment at USDOE facilities.

\section{REALISTIC RISK ASSESSMENT}

\subsection{Pilot Study Approach to Realistic Risk Assessment for USDOE Facilities}

The risk assessments in this document and in the companion documents for the SRS, FEMP and NTS are based on a realistic and objective approach to risk assessment. This approach to risk assessment contrasts with the approach recommended by USEPA for baseline risk assessments that are done as part of remedial investigation/feasibility studies (RUFS, USEPA 1989).

Baseline risks assessments are made according to USEPA guidelines, and the specifics of the analyses are usually dictated by the USEPA regional office responsible for the facility. Baseline risk assessments represent screening-level assessments because of the conservative assumptions embedded in the analyses and common use of simplistic transport models that produce approximate estimates of risk. A baseline risk assessment is conducted to escimate the risks associated with an identified operablt unit before any remediation of a USDOE site that is listed on the NPL. The assumptions used in the assessments are designed to protect public health and are generally conservative, and tend to overestimate risks. The USEPA has identified a number of appropriate environmental transport models for these assessments. They range from simple one-dimensional models to more complex computer codes.

The conservative assumptions contained in these baseline assessments include the previously described toxicity values and cancer risk factors, and worst-case conditions for land use, predicted environmental concentrations and exposure rates. The identified receptor for a baseline risk assessment is an individual receiving the "reasonable maximum exposure" [sic] (USEPA, 1989), whether or not she or he exists.

The results of the assessments of health risks are well documented in the pilot study, and scientifically defensible. Where realistic assessments were not appropriate because of a lack of site- and problem-specific information, detailed credible screening assessments were made to estimate the size of potential health risks, and to determirie what additional data collection is needed. The next section outlines the methods used for developing realistic risk estimates for problems at USDOE sites, and subsequent sections provide additional descriptions of the constituents of a "realistic" risk assessment.

\subsection{Steps in the Analysis}

The procedure outlined below was used in the pilot study for assessing human health risks at USDOE facilities. This procedure is the suggested generic approach for performing health risk assessments at USDOE facilities.

1. Development of Site Overview. The first step is to develop a site description that includes relevant background information on the physical setting of the site, nearby populations and land-uses, local meteorology, the direction of groundwater flow, and the uses of ground and surface water. 
2. Problem and Contaminant Identification. The impontant potenial problems and contaminants related to potential human exposures and risks are identified.

3. Source Term Characterization, Environmental Fate and Transport. The major chemical fate and transport pathways are described for the contaminants of concern. The temporal and/or spatiai variations of a contaminant's concentration in environmental media are predicted. Monitoring data and other available information are used to estimate the source term. Environmental transport models, adapted to the specific site, are used to predict contaminant concentrations.

4. Realistic Estimates of Exposure Rates. Potential human exposures to a substance of concern are estimated based on predicted concentrations of the contaminani in environmental media, at the point of exposure. These estimates are based on reasonable estimates of exposure parameters such as water intake, food intake, and residence time. Site-specific data are used when available. This step also includes the development of reasonable land-use scenarios.

5. Realistic Dose-response Relationships. Dose-response relationships, which relate toxic endpoints to exposures or doses are constructed or are identified in the literature. The safety factor approach used by the USEPA is replaced in the estimated relationship between dose and effect for toxicants by an explicit consideration of uncertainty. Cancer risk factors, are described as distributions about the best estimate available.

6. Risk Characterization. Finally, the potential individual and or population health risks and/or hazards for a specific environmental contaminant are quancified and described as probability distributions.

\subsection{Methods and Assumptions}

\section{Identification of Receptors}

Receptors are either people who are currently exposed to the pollutant of interest, or people who have a reasonable potential for such exposure. Currently exposed people include onsite populations (i.e., workers), and local or regional populations that are exposed because of environmental transpor processes (e.g., wind, surface and groundwater movement). Potentially exposed people include people that live in the path of a plume that is expected to reach them in the futuro, people that gain entry to the site as a result of a loss of institutional control, and additional people who may be exposed as a result of population growth.

\section{Development of Exposure and Land-Use Scenarios}

It is assumed that land-uses in the future conform to current activities, or to current activities on nearby land, unless there is compelling evidence to the contrary. Either ground water or nearby surface water is assumed to be the source of drinking water, unless there is evidence against such use.

The assumption of the maintenance or loss of institutional rontrol at a USDOE facility can be critical to the results of a risk assessment when most of the identified contamination is onsite in soil or water. A loss of institutional control may require the use of an intruder scenario, ard a scenario assuming the possibility of farming or a family living onsite. 


\section{Environmental Transport}

Contaminant concentrations in air, ground water, surface water and food are predicted by using environmental transport models appropriate to each site, each problem and the available data. Where complex site-specific transpon models were developed by the USDOE or site contractors, these models are considered for use in the assessments. When a large amount of historical data is available, empirical models are used to relate site contaminant discharges to environmental concentrations at receptors, in place of models that describe transport processes. These site-specific models allow the formulation of reasonable estimates of temporally related contaminant releases.

When sites and source terms are poorly characterized, more elementary models are developed and applied. Such models provide appropriate estimates of future environmental concentrations of the principal contaninants of concern, for use in a site-specific, riskbased screening analysis.

\section{Exposure Routes and Parameters}

Each route of exposure is analyzed for its contribution to the total exposure of a person to a contaminant. The analysis relates the concentration of contaminant in a medium (e.g. . $\mathrm{pCi} / \mathrm{L}_{\mathrm{H}_{2} \mathrm{O}}, \mathrm{mg} / \mathrm{kg}_{\text {soil }}$ ) to the total amount of the medium to which an individual is exposed. The data used in the analyses include distributions of pathway exposure factors (Table 1). These distributions reflect population characteristics in the United Sates, enther obtained from published sources or developed from available data. Specific pathways of exposure are not analyzed further when documented evidence shows that they are not appropriate to the specific problem or do not contribute substantially to the overall risk.

\section{Dose-response Relationships and Risk Characterization}

For each contaminant, a dose-response function is applied to the total dose from each exposure pathway. A dose-response function is a general tern for the effect on a specific target organ, or the body as a whole, per unit of contaminant dose delivered to the organ or taken into the body. Available published dose-response functions are used, when appropriate. Dose-response finctions are developed from published data, when such functions have not been estaulished, or when published dose-response functions are unsuitable for low-dose levels.

Hazards are detrimental effects, characierized qualitatively and quantitatively for carcinogenicity and/or toxicity. Published risk functions (factors), based upon the doseresponses for these end points, are used, when available and appropriate. These risk íctors, expressed as risk per unit dose, or risk per unit intake, ore applied to the total doses (or intakes) of contaminants to estimate the risks. In most cases the risks are estimated for cancer mortality (Table 1), including irdividual lifetime risks and population risks. These risks are expressed as central values (average and/or median) and uncertainties (standard deviation and cumulative upper $95 \%$ probability value). Graphic examples of the ranges of risks are also reported. For effects other than cancer (i.e., toxicity) the risks are expressed as the probability of an individual incurring the effects, including a central value (mean or median) of the risk and uncertainty in its expression.

In the absence of published risk factors, they are developed from the data for a specific contaminant. Published risk factors are subject to reinterpretation because they are established by regulatory agencies to serve the risk management aim of public health 
protection, rather than health risk assessment. The protective function is achieved by the incorporation of conservative assumptions (e.g., assumptions that use upper bound values for parameters; assumption of lifetime exposure) and multiplicative safety factors. To obtain more accurate risk assessments, these risk factors are developed independently, where necessary and possible, from published data.

Table 1. Selected Comparisons of Parameter Values Recommended by the USEPA, With Quantitative Expressions for the Same Parameters in the Pilot Study Risi' Asssessments for the Savannah River Site (SRS).

\begin{tabular}{|c|c|c|}
\hline Parameter & USEPA & Pilot Study (SRS) \\
\hline \multicolumn{3}{|l|}{ Exposure } \\
\hline Duration (years) & 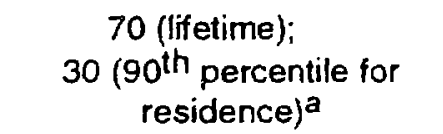 & $\begin{array}{c}\text { Based on each year of } \\
\text { exposure }\end{array}$ \\
\hline Body Weight (kg) & $\begin{array}{l}70 \text { (average adult) } \\
\text { and age specific values }\end{array}$ & $\begin{array}{l}\text { Age weighted lognormal } \\
\text { distribution: Average, } 58\end{array}$ \\
\hline Surface Area, Total Body $\left(\mathrm{m}^{2}\right)$ & $\begin{array}{l}\text { Age specific } 50^{\text {th }} \text { percentile } \\
\text { values; } 50^{\text {th }} \text { percentile for } \\
\text { average }(70 \mathrm{~kg}) \text { adult is } \\
\text { recommended. }{ }^{a}\end{array}$ & $\begin{array}{l}\text { Age weighted lognormal } \\
\text { distribution: Average, } 1.5\end{array}$ \\
\hline Irihalation Rate & $\begin{array}{c}20 \mathrm{~m}^{3} \text { per day (average } \\
\text { adult) }\end{array}$ & $\begin{array}{l}\text { Age weighted lognormal } \\
\text { distribution: Average, } 0.4 \mathrm{~m}^{3} \\
\text { per } \mathrm{kg} \text { per day }\end{array}$ \\
\hline Time in Shower (min) & $12\left(90^{\text {th }} \text { percentile }\right)^{a}$ & $\begin{array}{c}\text { Lognormal distribution: } \\
\text { Average, } 7.8\end{array}$ \\
\hline Drinking Water Intake (LD) & \left.$2{\left(90^{\text {th }}\right.}_{\text {percentile })}\right)^{\mathrm{a}}$ & $\begin{array}{l}\text { Age weighted lognormal } \\
\text { distribution: Average, } 1.2 \\
\text { (region specific) }\end{array}$ \\
\hline Finfish Intake (kg/year) & $2.73(\text { based on } 6.5 \mathrm{~g} / \text { day })^{a}$ & $\begin{array}{c}\text { Age weighted lognormal } \\
\text { distribution: Average, } 7.7 \\
\text { (region specific) }\end{array}$ \\
\hline Risk Factors : & Individual Lifetime Risks for & $\frac{\text { Cancer Mortality }{ }^{b}}{\text { Lognormal distributions: }}$ \\
\hline Tritium (per $p C_{1}$ ) & $5.5 \times 10^{-14}$ (ingestion) & Average, $4.4 \times 10^{-14}$ \\
\hline
\end{tabular}

a USEPA 1989 recommends use of the 95th or 90th percentile level to estimale reasonable maximum exposure, except where indicated otherwise.

b USEPA (1991) slope factors at the time of performance of the risk assessments. The bases for most of the EPA slope factors for radiation are not explained in the document. In most cases dose and risk factors in the Pilot Study are not directly comparable to USEPA values because of differences in derivation. In the Pilot Study, many of these factors are based on retention functions, and reanalysis of individual organ doses. 


\section{Probabilistic Assessment and Uncer:ainty}

A realistic arid probabilistic assessment uses the range of possible values for parameters and variables, rather than relying on single values. Table 1 provides examples of distributions of parameters used in the pilot study for the SRS, and corresponding values recommended by the USEPA for risk assessments. For example, the rate of drinking water intake by individual receptors is reprasented by a distribution of values of intake, instead of the single high rate of intake commonly used in USEPA and USDOE risk calculations. Parameter values under the EPA heading may not appear to be very different from the correrponding values under the Pilot Study (SRS) heading in table 1. However, in a Superfund type of risk assessment, the interactions of conservative assumptions and factors compound the overall uncertainty of the assessment (Burmaster and Harris. 1993). This compounding makes it difficult to sort out the individual contributions to the overall uncertainty of the assessment, in contrast to a realistir risk ass"ssment, where the uncertainty for each assumption or factor is described as a distribution of parameter values. It is important to note that a realistic risk assessment may yield an overall uncertainty that is more than one order of magnitude lower than the overall uncertainty in a Superfund assessment; a difference that can influence a decision for or against initiating expensive remedial actions.

The realistic approach to risk assessment allows an estimate of the uncertainty associated with an "average" or "worst-case" risk estimate. As described above, the result of such an assessment for cancer mortality risk is a distribution that can be presented graphically, along with the mean risk and $95 \%$ upper confidence limit (i.e., cumulative upper $95 \%$ value) risk.

Many of the probabilistic analyses in the pilot study were produced with a Monte Carlo analysis, using Crystal Ball ${ }^{\text {TM }}$ (Decisioneering, Boulder, $\mathrm{CO}$ ) software. In a Monte Carlo analysis, a sample from the distribution of a variable is placed into a simulation run (iteration) to interact with samples from distributions of other variables. The frequency of sampling within a distribution of a variable depends upon the relative frequency of a value in that distribution (P-ustenbach et al., 1991).

\section{Inadequate Data and Screening Assessment}

Part of the risk assessment process developed in this pilot study is the exercise of professional judgment concerning the amount (and quality) of site characterization and source-term data needed to justify the application of simple versus complex models, and the probabilistic methods required for a "realistic" assessment. When source term or site characterization data are limited, a screening level assessment is the only feasible approach to assessing a problem. The screening-level assessment approach used in this pilot study was to: (a) do such screening assessments when the available data were limited (eliminating unnecessary conservatism where possible); (b) document explicitly all assumptions used in the analysis; and (c) draw conclusions on the need for additional data collection. 


\section{PILOT STUDY SUMMARY}

\subsection{Introduction}

In the pilot study, the problems chosen for assessment at the SRS were the release of tritium and ${ }^{137} \mathrm{Cs}$ to surface water. For the FEMP, problems assessed were the release of radon from the $\mathrm{K}-65$ silos and uranium in offsite ground water. Plutonium contamination of surface soil and radionuclide contamination in ground water were assessed for the $\sqrt{1} S$. The results of these risk assessments are summarized here, and presented in detail in Hamilton et al., 1993a, Hamilton et al., 1993b, Layton et al., 1993, and Daniels et al., 1993. Table 2 cummarizes the scerarios and receptors included in the pilot study, table 3 outlines the major transport pathways, and table 4 outlines the exposure pathways.

Table 2. Scenarios and Receptors in the Pilot Study

\begin{tabular}{|c|c|}
\hline Scenario & Aeceptors \\
\hline $\begin{array}{l}\text { Beleases of }{ }^{3} \text { Hand }{ }^{137} \text { Ss from the SRS to the } \\
\text { Savannah River } \\
\text { 1. No reactor operations after } 1989 \\
\text { 2. Full K-Reactor operation begins in } 1993 \\
\text { Badon Releases from K- } 65 \text { Silos at the FEMP } \\
\text { 1. Continuous Releases } \\
\text { 2. Release subsequent to collapse of one } \\
\quad \text { silo dome } \\
\text { Groundwater Uranium Plume emanating from } \\
\text { the FEMPb } \\
\text { 1. Continuous Release } \\
\text { 2. Release is Stopped } \\
\text { Soil Plutonium al the NTSC } \\
\text { Loss of Institutional Control: } \\
\text { 100 years: } 50,000 \text { years; } 100,000 \text { years }\end{array}$ & $\begin{array}{l}\text { People supplied by two drinking water planis } \\
\text { that draw river water approximatehy } 160 \mathrm{~km} \\
\text { downriver from the SRS } \\
\text { Onsite workers and offsite residenis }\end{array}$ \\
\hline
\end{tabular}

a Hamilton et al., 1993a

bHamilton et al., $1993 \mathrm{~b}$

CLayton et al., 1993

dDaniels et al., 1993 
Table 3. Environmental Transport in the Pilot Study Assessments

\begin{tabular}{|c|c|}
\hline Contaminant & Transport \\
\hline $\begin{array}{l}\text { 3H as HTO at the SRS } \\
137 \text { Cs at the SRS } \\
\text { Radon at the FEMPb } \\
\text { Uranium at the FEMPb } \\
\text { Plutonium at the NTS } \\
\text { Padionuclides at the NTS }\end{array}$ & $\begin{array}{l}\text { Solution in Savannah River Water } \\
\text { Solution or Susperision in Savannah River Water } \\
\text { Atmosphere } \\
\text { Ground Water } \\
\text { Atmospheric Resuspension of Soil } \\
\text { Ground Water }\end{array}$ \\
\hline
\end{tabular}

aHamitton et al., 1993a

bHamilton et al., 1993b

CLayion et al., 1993

dDaniels et al., 1993

Table 4. Major Exposure Pathways in the Pilot Study Assessments

\begin{tabular}{|l|l|}
\hline Contaminant & Major Exposure Pathways (from highest to lowest exposure) \\
\hline $\begin{array}{l}3 \mathrm{H} \text { as HTO at the SRS } \\
137 \text { Cs at the SRS }\end{array}$ & $\begin{array}{l}\text { Drinking Water Intake, Inhalation in the Shower } \\
\text { Freshwater Finfish Intake, Drinking Water Intake } \\
\text { Radon at the FEMPb } \\
\text { Uranium at the FEMPb }\end{array}$ \\
$\begin{array}{l}\text { Inhalation } \\
\text { Drinking Water Intake, Food and Milk Intake }\end{array}$ \\
$\begin{array}{l}\text { Plutonium at the NTSC } \\
\text { Radionuclides at the NTSd }\end{array}$
\end{tabular}

a Hamilton et al., 1993a

bHamitton et al., 1993b

CLayton et al., 1993

dDaniels et al., 1993

\subsection{Savannah River Site Risk Assessments}

Health risks were assessed for releases of tritium and ${ }^{137} \mathrm{Cs}$ from the Savannah River Site (SRS) at water-receptor locations downriver (Table 2). Liquid waste releases to the Savannah River continue either by direct discharges into onsite surface waters or by groundwater transport into surface waters from waste facilities, although reactor operations were shut down at the SRS in 1989. Existing state mandates require that liquid waste streams from future operations go directly into surface waters. Two drinking water processing plants take water from the river approximately $160 \mathrm{~km}$ downriver from the SRS. The domestic populations supplied by these facilities are expected to increase from 57,000 , in 1990 , to 367,000 , by the year 2000 . Potential incremental risks of cancer fatality to individuals and each population were analyzed for two scenarios:

(1) no further reactor operations; and

(2) resumption of operation of one specific reactor.

The major radioactive component of the releases (approximately 99\%) is tritium. SRS data, based on actual measurements back to 1954, under varying conditions of operation, were used to develop an empirical model to predict annual releases of tritium to the 
Savannah River, and tritium concentrations in the water at the receptor locations. Groundwater migration (from varying previous releases to waste facilities) was expected to be a component of the source terms until the year 2004, with the source terms remaining unchanged in all subsequent years. The major exposure pathways for the receptor populations (Table 4) are ingestion of tap water (85\%), and inhalation of water vapor while bathing in the home (15\%). Exposures from other pathways are lower by at least one order of magnitude. Lifetime cancer mortality risks were calculated for each year of exposure, from 1992 through 2004, because exposures were expected to vary and then remain unchanged in subsequent years. The $95 \%$ cumulative level of incremental lifetime risk of cancer death for an individual was $8 \times 10^{-7}$ for the year of predicted maximal exposure, 1993. For lifetime exposures to tritium released to the Savannah River, no deaths were predicted in either receptor population.

Less than $600 \mathrm{Ci}$ of ${ }^{137} \mathrm{Cs}$ was released to onsite streams from SRS operations since 1954 , most of which has bound to sediments of the stream beds of the onsite tributaries. Less than half this amount remain s because of the combined effects of radioactive decay, solution, and resuspension discharge to the Savannah River. Less than $0.5 \mathrm{Ci}$ per year was the estimated rate of discharge to the river, to be maintained into the furst quarter of the twenty-second century, in the presence or absence of further operations at the SRS. Tha major exposure pathways for the receptor populations described above are ingestion of finfish taken from the river, and ingestion of tap water (Table 4). Exposure from fish ingestion averages 9 to 18 times greater than drinking water exposure, because of ${ }^{137} \mathrm{Cs}$ bioconcentration in fish, and removal of ${ }^{137} \mathrm{Cs}$ from domestic water supplies by the water purification plants. Lifetime cancer mortality risks were calculated for each year of exposure. The $95 \%$ cumulative level of incremental lifetime risk of cancer death of an individual was less than $10^{-8}$ per year of exposure. No deaths were expected in either receptor population as a result of lifetime exposures to ${ }^{137} \mathrm{Cs}$ released to the Savannah River.

These assessments employed realistic distributions of parameter values in place of conservative default values, to yield prouabilistic predictions of risk and their associated uncercainties.

\subsection{Fernald Environmental Management Project Risk Assessments}

The two important environmental problems studied at the FEMP were radon emissions from the K-65 waste silos, and offsite contamination of groundwater with uranium.

The assessment of radon emissions from the silos at the FEMP involved the development of a source term (based on available monitoring data), and the prediction of exposure and risk of lung cancer to fenceline residents, residents within 1 and 5 miles of the silos, and residents of Hamilton and Cincinnati, Ohio. A gaussian plume model and site meteorological data were used to make these predictions for two release scenarios:

(1) continuing, routine release of radon from the silos; and

(2) an accidental loss of the radon contained in the head space of a silo dome, because of collapse of the dome.

Time indoors, time living at a residence, and the risk factors for racion were descrithed as distributions based on available data. The exposures and risks associated with background radon concentrations were also estimated. 
Radon and radon progeny associated with the K-65 silos were estimated, under the routine release scenario, to produce individual lifetime risks (lung cancer) greater than $1 \times$ $10^{-4}$ only for onsite indoor workers (mean: $4.3 \times 10^{-4}$ ) and fenceline residents (median: $1.8 \times 10^{-4}$ ). Population risks, associated with the routine and accidental release scenarios, were less than one per lifetime for all identified receptor populations (within 1 mile of the site boundary; within 5 miles of the site boundary; Hamilton, Ohio; Cincinnati, Ohio). The individual and population risks associated with background radon concentrations (median individual risk: $7.3 \times 10^{-3}$ ) were 1 to 4 orders of magnitude iarger than the risks associated with radon emissions from the silos.

The uranium risk assessment was based on model prediciions performed by IT Corporation, using a calibrated, three-dimensinnal groundwater flow and transpor model. Historical releases have formed a plume of uranium in the ground water south of the FEMP. The concem was for toxic effects and/or an increased risk of cancer to people using ground water. Two scenarios were considered (Table 2):

(1) a continuing source of uranium to ground water; and

(2) no additional (stop) source.

Exposures and risks were estimated 70 years into the future, for currently located residential wells, potential future wells located along the center of the developing plume, and all possible future well locations in the impacted area.

Exposure routes included in the assessment (Table 4) were water ingestion, intake of home-grown food and home-produced milk. Intake rates for water, food and milk were based on distributions derived from published data. The cancer risk assessment was based only on exposures associated with uranium in ground water emanating from the FEMP (direct water ingestion, ingestion in food irrigated with contaminated water, and ingestion in milk from cows watered with contaminated water). Because toxicity is a threshold effect, the toxicity assessment included exposures to milk contaminated as a consequence of dairy cattle eating uranium in soil and vegetation (not associated with groundwater contamination), as well as the use of uranium-contaminated ground water associated with the FEMP.

The toxicity risk assessment was baseci on a pharmacokinetic model and parameter distributions derived from the published literature. A distribution of threshold for uranium toxicity in the kidray was developed from data available in the literature. The probability of a toxic effect was defined as the probability of kidney uranium concentration exceeding the threshold.

The cancer risk assessment was based on ALI values (annual limits on intake) for workers (integrated dose per 50-year working life span; ICRP, 1979, 1991a,b), modified to reflect a distribution of gut-uptake factors, and allowing dose to be committed for the remaining years of a 70-year lifetime following the last year of exposure.

No toxic effects were predicted for currently located receptor wells or for potential wells located along the centerline of the developing plume. An assessment incorporating the uncertainty in transport and food chain model predictions, and in the pharmacokinetic model formulation, yielded a predicted $4 \times 10^{-6}$ probability of exceeding a kidney toxicity threshold for any randomly located well south of the FEMP in 1989 and in the next 70 years. 
All estimated cancer risks were small. The largest predicted individual lifetime risk (1.3 $\times 10^{-5}$ ) was for a residential well. The predicted individual lifetime cancer fatality risks for wells located anywhere south of the facility were always less than $2 \times 10^{-5}$. Predicted risks for both the stop and continue source scenarios were similar because most exposure is ass. ated with uranium discharged before 1989. Additional uncertainties (from groundwater and food-chain models and dose estimates) had little effect on the risk estimates.

\subsection{Nevada Test Site Risk Assessments}

The Nevada Test Site (NTS) is located in southwestern Nevada, about $105 \mathrm{~km}$ (65 miles) northwest of the city of Las Vegas. In the late 1950s and 1960s a series of tests was conducted at or near the NTS to study safety-related issues involving plutoniumbearing devices. These tests resulted in the dispersal of about $5 \mathrm{TBq}$ of ${ }^{239.240} \mathrm{Pu}$ on the surficial soils at the test locations. Additionally, underground tests of nuclear weapons devices have been conducted at the NTS since late 1962; ground water beneath the NTS has been contaminated with radionuclides produced by these tests. These two imporant problems were selected for assessment.

Potential cancer risks were estimated for human exposures to the residual plutorium in soils, based on the assumption that institutional controls are lost over the affected areas in 100 years. Three basic exposure scenarios were defined that could bring individua's in contact with the $239.240 \mathrm{Pu}$ contaminated soils at that time (Table 2):

(1) a resident living in a subdivision:

(2) a resident farmer;

(3) and a worker at a commercial facility.

Incremental cancer risks were then predicted for an individual in each category. The 5 , 50 , and 95th percentile risks for the resident farmer at the most contaminated site were $4 \times 10^{-6}, 6 \times 10^{-5}$, and $5 \times 10^{-4}$, respectively. The median cancer risk for the farmer is a factor of three higher than for the suburban resident and a factor of ten higher than for the worker. Key sources of uncertainty in the estimated risks were population mobility, the relationship between indoor and outdoor contaminant levels, and the dose and risk factors for bone, liver, and lung.

Continued population growth and expanding development in the southern part of Nevada, and the possible loss of institutional control at the NTS after 100 years led to a concern that individuals in future generations might become exposed to ground water contaminated by radionuclides introduced at the NTS. Therefore, for human ingestion of these radionuclides in NTS ground water, we estimated the potential excess lifetime risk of cancer mortality in two scenarios (Table 2):

(1) onsite exposure, because of the assumed loss of institutional control after 100 years;

(2) and offsite exposure, because of radionuclide migration in ground water to the nearest accessible environment (considered to be $19 \mathrm{~km}$ southwest of the northwestern boundary of the NTS). 
The estimated lifetime risk of excess cancer mortality ranges from $3 \times 10^{-3}$ to $2 \times 10^{-2}$ for onsite exposure, and from $7 \times 10^{-7}$ to $1 \times 10^{-5}$ for offsite exposure. Both the of fsite and onsite estimates of risk are dominated by the lifetime doses from tritium. The onsite estimate of risk suggests the need for a contingency plan for the continuation of institutional control. The of fsite estimate of risk is within U.S. Environmental Protection Agency (USEPA) goals and does not pose a serious concern. The critical uncertainty is the concentration today of radionuclides in ground water beneath the entire NTS.

Nevertheless, uncertainties in radionuclide concentration, consumption rate, and dose- and risk-conversion factors were all addressed.

\section{LESSONS LEARNED: INFORMATION AND METHODS NEEDED FOR IMPROVEMENT OF RISK ASSESSMENT AT USDOE FACILITIES}

\subsection{Frobabilistic Methods}

The pilot study demonstrated the usefulness of the probabilistic approach to risk assessment. A number of pirfalls and problems were identified in the application of the probabilistic approach to using parameter distributions in the pilot study, either obtained from published literature sources, or derived from available data.

Selection of types of distributions of parameter values (assumptions) must be justified clearly. In some cases the distribution of values can be tested statistically. For example, lognormal distributions are commonly applied to environmental data, since these data contain non-zero values that are often positively skewed. The tests for a lognormal distribution are simple. Lognormally transformed individual sample values generally exhibit a normal distribution pattern (Blackwood, 1990) and show linearity in a logprobability plot (Roseberry and Burmaster, 1992). However, professional judgment may be used to select lognormal distributions, but the reasoning behind such decisions must be explained. Lognormal distributions can also be substituted for normal distributions without creating a substantial error in calculations (Blackwood, 1990).

In cases where there are insufficient data, the choice of a distribution type is based On professional judgment and is more uncertain. This can happen when the lower and upper extreme values of a parameter are known, but intermediate sampling is insufficient. One might assume that there is an equal chance for any value between the extremes (a uniform distribution), or one might select an intermediate value as a mode (a triangular distribution). Alternatively, commercial Monte Carlo software allows one to set up a custom distribution in which calculation sam ples are selected in proportion to the frequency of the available measured values for a specific parameter.

Another source of possible error comes from assumptions of independence of parameters. For example, the amount of daily milk ingestion may bear a relationship to daily water ingestion. Consumption of foods may be significantly related to body weight. Consumption of foods, as well as other human behavior, may also have importani agerelated properties.

In its "Guidelines for Exposure Assessment" the USEPA (1992a) has defined uncertainty and variability. Uncertainty of an estimate is "the lack of knowledge about the correct value for a specific value for a specific ... estimate". Variability within a population 
contributes to uncertainty as "the receipt of different levels of exposure by different individuals". These definitions can be extended to other steps in the risk assessment process, as well as to specific parameters in exposure assessment. Thus, there is variability and uncertainty in source terms, dose-response relationships, and risk characterization.

A systematic approach is needed for identifying major sources of uncertainty in risk assessments at USDOE facilities, and for development and application of methods to reduce those uncertainties. Risk assessors need guidance on how to select or create distributions for particular applications, what to do in the absence of high-quality information, and what are the implications of incorrect choices or simplified assumptions about distributions. Better data are often needed to describe important parameters, thus improving probabilistic approaches (e.g., information on correlation among exposure parameters).

\subsection{Land-Use Scenarios and Receptors}

One of the lessons learned in the pilot study assessments is the critical importance of the land-use scenarios and individual receptors identified in the assessment.

\section{Land-Use Scenarios}

Choice of reasonable land-use scenarios is often difficult. Reasonable scenarios must account for current practices in land-use in the area of the specific site, and geophysical and natural conditions that preclude altemative scenarios (e.g., natural ground water contamination that precludes use for drinking water).

Three potential land-use scenarios (all onsite after a loss of institutional control) were considered in the risk assessment for plutonium-contaminated soil at the NTS (Table 1); residential, farm, and commercial use (Layton et al., 1993). The $50 \%$ cumulative cancer risk at 100 years for the farming scenario was 6 to 7 times the risk for commercial use. This suggests the importance of including reasonably possible alternative land-use scenarios in a risk assessment.

Assumptions about duration of institutional control exert major impacts on the entire analysis. The analysis of the risks of Pu at the NTS was sensitive to the type of land-uses selected for analysis. Differences in the types of buildings, and human factors (e.g., time spent outside at home, time at a given residence, occupational mobility, etc.), affected the magnitude of inhalation exposures, and hence, doses to target organs. One method of dealing with alternative land-uses for a given site is to develop a probability tree that specifies the likelihood of each potential land-use based on site-specific factors (e.g.. availability of water, terrain, etc.).

\section{Receptors}

Identification of reasonable receptors can also be difficult. Most risk assessments place the individual human receptor directly in the path of a developing ground water or air contaminant plume, or at the site boundary where environmental concentrations will be highest. Such assessments also assume that the highest concentration (measured or predicted) represents that receptor's lifetime exposure. This commonly used approach overestimates exposures (and risks). 
In the pilot study, currently located receptors presented no problem. Receptors were located at actual private homes (FEMP-Hamilton et al., 1993b) or water usage points (SRS-Hamilton et al., 1993a). For current exposures and risks no assumptions need be made about where to place the receptors-they already exist!

Locating future receptors, especially in the case of ground water contamination that varies over space and time, presented more of a problem. In the risk assessment for radionuclides in ground water, at the NTS, limited site characterization data (i.e., direction and rate of groundwater flow) forced a conservative approach in identifying potential future receptors (Daniels et al., 1993). The general direction of groundwater flow and current population density were used to model an offsite population near the western edge of the site (Table 2). This population was assumed to represent a future receptor for all groundwater contamination emanating from a generalized area beneath the NTS.

It was possible io treat receptors more realistically in the risk assessment for groundwater contamination by uranium at the FEMP (Hamilton et al., 1993b). Groundwater uranium concentrations over a 70-year lifetime were predicted (using a calibrated groundwater transport model) for each grid cell ( $125 \times 125$ feet) of the model domain south of the facility. Each cell was assumed to represent a potential future wcil. The probability of a future well location exceeding particuliur levels of individual lifetime cancer risk (i.e., probability of locating a well with risk greater than $1 \times 10^{-6}$ ) and the probability of a future well exceeding the toxic threshold for kidney effects were estimated.

Better approaches and methods are needed to identify potential future receptors of contamination emanating from USDOE facilities. For example, the probabilistic approach used at FEMP should be intproved to account for terrain and other factors (including alternative land-uses and population growth) that might affect the location of future wells.

\subsection{Site and Source Term Characterization}

The pilot study found that the quantity of data available at USDOE sites varies considerably. Sites that historically have large-scale monitoring efforts (e.g., the SRS) or have begun the RU/FS process, mandated under Superfund, (e.g., the FEMP) have a large amount of data. Other sites (e.g., the NTS) have scarce data on contaminant levels, spatial contaminant distribution, or physical characteristics of the site, such as hydrogeology. The absence of historical data (e.g., the NTS) hampers the application of models that use temporal trends in contaminant release and movement to predict source terms in scenarios for the future of a site.

A major uncertainty at USDOE facilities is the description of source terms. Both the mass of contaminants at a facility and the rate of their migration to the environment are often largely unknown. The pilot study demonstrated that, in a number of cases, reasonable estimates of source terms can be derived from historical information and monitoring data, reducing the reliance on worst-case estimates. Reasonable source terms were estimated for ${ }^{137} \mathrm{Cs}$ and tritium migration to the Savannah River, radon emissions from the K-65 silos at FEMP, uranium in ground waier at FEMP, and plutonium in surface soil at the NTS.

The pilot study assessments also found that, in at least one case (ground water contamination at the NTS), source terms and site characteristics were insufficient to derive "realistic" source terms with a high degree of confidence. In this case, the only credible 
approach to the analysis was to make practical worst-case assumptions, while addressing transport, exposure, dose and risk probabilistically.

\subsection{Transport Models and Physical Parameters}

The pilot study found that environmenual transport models and the physical parameters used as input to the models play a critical role in the risk assessment process.

The uncertainties associated with model predictions are associated with a number of factors. There are uncertainties associated with the model formulation and with the appropriate application of a model to specific field situations (e.g., use of a groundwater model designed to simulate contaminant transport in porous media applied to a site with more coinplex geology).

There are also uncertainties associated with the physical parameters used as input to the models. Physical parameters may be uncertain because of a lack of knowledge í $\epsilon . z$., physical parameters at NTS), or because they are naturally variable (e.g., water flow rates in the Savannah River). Quantitatively unpredictable phenomena, such as drought effects at the SRS, are superimposed on the uncertainty that is derived from natural variation.

There are three levels of modeling complexity to consider for risk assessments:

(1) Relatively simple models;

(2) Relatively complex, sophisticated models; or

(3) No formal models.

There is no generic answer to the question of whether complex models are cost effective. Cost effectiveness is a balancing equation and the balance will be case specific. Generally, a complex model should only be developed for a specific site when:

(1) A preliminary assessment determines that a generic model contributes a major uncertainty in the overall assessment results; and

(2) The daia base is adequate for testing and validation of the model.

In the assessment of radionuclide transport in ground waier, at the NTS, the extremely limited amount of site characterization information precluded the use of a complex model such as the one employed at the FEMP. Instead, a travel-time-transport approach was used for the NTS. Importantly, the travel-time-transport model considered parameter uncertainty, and any possible correlation among parameters. The principal outputs of this approach were probability density functions conditioned on the sets of parameters used to describe processes such as velocity, advection, dispersion, and radioactive decay. These outputs predicted concentrations of annual groundwater contaminants at the receptor location. These predicted concentrations were assumed to be geometric mean values of lognormally distributed variables. Each annual value was also considered to be associated with a significant degree of uncertainty that could be represented by a geometric standard deviation equal to 2.0 .

Use of standard (generic) models and data, without site and regional characterization, can contribute to uncertainty because standard transport models may not be able to handle complex site-specific situations with the greatest accuracy. Even 'simple' groundwater models require considerable input data. The groundwater component of DOE's Multimedia Environmental Pathway Assessment, for example, requires dozens of input parameters. Some of the simplification is not just in the modeling, but in using generic or default values 
for these parameters. On the other hand, a sophisticated model may have less uncertainty associated with the predictions, but this uncertainty can be more difficult to quantify because of the complexity of the model.

Although use of an existing generic model may appear to be the most cost effective approach in a risk assessment, more complex models can be very cost effective on the bases of several considerations.

(1) Costs of remediation are far greater than risk assessment costs. "A risk assessment...could significantly expedite cleanup cycles and ultimately save the facility millions of dollars" (Callahan and McCaw, 1993).

(2) A need for best allocation of limited resources available for remediation choices. More complex models provide both better understanding of how much remediation is really needed and other information. By reducing uncertainty and possibi; conservative assumptions, sophisticated models can help to set priorities for remediation, with savings on costs for remediating what are perceived to be problems when generic methods are used.

(3) The major purtion of money needed for development of the sophisticated models has already been spent, with minimal cost to the risk assessment project.

The amount of additional information to be gained from a complex model will depend, in part on the amount of data available. Sophistication of the transport model should matith the data available at the site. Complex models require more data than simple models. If site-specific data are not available, and generic data must be used as input, much of the value of a more complex model will be lost. By running several cases with a range of data inputs, a complex model may be used in an assessment to help determine the value of obtaining additional data. This is a cost-effective approach because modelling is less expensive than field work.

Although complex models cost more to use than simple generic models, they also provide more and better information. Cost effectiveness depends on value of increased information relative to increased modeling cost. The value of additional information includes greater confidence provided to decision makers and the public, and the potential savings in future remediation costs resulting from better information.

A lesson learned in the pilot study is that complex environmental transpon models have been developed by USDOE and site contractors at many USDOE facilities. These models, sometimes with minor modifications, may be extremely useful in risk assessments, and yield better estimates of environmental concentration than simpler, more generic models.

For example, a calibrated, three-dimensional model was developed by IT Corporation for predicting uranium transport in ground water at the FEMP. USDOE had already spent time and resources in the development of this model, and it was superior to any modeling that could be completed independently in the short time available for the pilot study risk assessment. However, the usefulness of the original model output was limited in the risk assessment for uranium. No output was available other than contour maps, and these maps did not show predicted concentrations less than the proposed drinking water standard for uranium. Originally, predictions were not available except for years 0 and 70 . By agreement with USDOE, IT Corporation reran the model to produce results for every tenyear interval of a 70-year lifetime, and provided the data in electronic form sor use in the risk assessment.

Another lesson learned in the pilot study is that transport models are not always necessary. A large amount of historical data was collected at the SRS, describing the 
concentrations of radionuclides in the Savannah River downstream of the facility. These data were used to generate an empirical relationship between radionuclide concentrations in the river and operating status of the SRS reactors. This avoided the need to devciop a transport model for radionuclides in the river and the uncertainty associated with the source term over time.

Additional work is needed to provide guidance to risk assessors on how to quantify uncertainty in complex transport models and how to reduce the uncertainty associated with physical parameters. Monte Carlo methods, additional data collection, and other approaches (e.g., use of empirical models and use of geochemical models to estimate $K_{d} s$ binding coefficients of contaminants to soils, particulates, and sedimenis in stream beds) may all help to reduce the uncertainty in model predictions and to quantify the uncertainty that is unavoidable. A major factor to be determined is the degree of influence on exposure to harmful forms of contaminants by physico-chemical characteristics of site-related media and by the general bioavailability of these contaminants. For example, chromium may be present in soil as either relatively harmless $\mathrm{Cr}$ (III) or as the inhalation carcinogen $\mathrm{Cr}$ (VI) (Paustenbach et al., 1991). Much of this work requires basic scientific laboratory and field investigations.

\section{Biotransfer Factors}

There is a need for additional data describing the concentrations and transfer to humans of major contaminants encountered at USDOE facilities. Only limited data are available for a number of chemicals (primarily organics), although biotransfer factors have been compiled for major radionuclides encountered at USDOE sites (Till and Meyer, 1983; USNRC, 1977). Improvements in the estimation and availability of biotransfer factors are needed to improve risk assessments at USDOE facilities. As discussed in the previous section, information is also needed on the influence of physico-chemical characteristics of environmental media on bioavailability of contaminants.

Many of the health risk assessments at USDOE facilities will include pathways through edible fish, meat, milk, fruits and vegetables to humans. Tritium and cesium transfers through edible fish were considered in the Savannah River Site assessment, and uranium transfers through milk and homegrown fruits and vegetables were included in the risk assessment for the Fernald Environmental Management Project. Unfortunately, for contaminants of concern at USDOE facilities, there are little published data to support the estimation of biotransfer factors. The pilot study risk assessments developed biotransfer factors from these limited data, or from other site-specific data.

\subsection{Exposure Calculations}

A detailed description of all exposure pathways for human contacts with each contaminant should be done early in the assessment procedure, to reduce the possibility that potentially important exposure mechanisms are overlooked. Screening-level calculations are then carried out to determine which pathways are the most important so that extra effort is directed toward descriptions and reductions of uncertainties of parameters in those pathways rather than ones that are less important. For example, the dominant exposure pathway was shown to be inhalation for plutonium in soils at the NTS. Consequently, we focused on factors that directly affected the magnitude of inhalation exposures. Those factors included resuspension, breathing rates, and relationships of time spent indoors to time spent outdoors. 


\section{Exposure Parameters}

Exposure parameters can vary with age, sex, region and time of year. Published data and analyses of water ingestion rates (Ershow and Cantor, 1989; Roseberry and Burmaster, 1992) are examples of information that was useful in the risk assessments at the SRS, the FEMP and the NTS. Better information is needed on food intakes (e.g., amount of recreationally caught fish eaten), time spent indoors, exposure frequency and period (years of residence in one place). In some cases, generic or even regional exposure data are available, but the data are not organized and available in a way that is helpful for risk assessments.

One of the most widely used data sets in human health risk assessment is a database developed by the U.S. Department of Agriculture (USDA) that describes the amounts and kinds of food eaten by people in the United States (USDA 1984, 1989). These data were derived from surveys of 30,700 people between 1977 and 1978. The mean intakes of various food categories by region, age, and socioeconomic status were published by USDA. An additional analysis of these data was perfonned by USEPA.

These data sources were used in the risk assessment for the FEMP to describe the amounts of fruit, vegetables and milk consumed by people living near the facility, and the percentage of food and milk that was produced at home. Unfortunately, the statistics reported for the USDA database did not provide all the information necessary for a probabilistic risk assessment, and a number of simplifying assumptions had to be made in the pilot study analysis. The types of statistical information needed included: mean and standard deviation for the entire population included in the data base; standard deviations for age groups; mean and standard deviation of the total amount of fruits and vegetables grown at home; mean and standard deviation of the amount of fresh milk and other dairy products consumed; and mean and standard deviation of the portion of fresh milk and other dairy products consumed that are produced at home.

In addition, most risk assessments (including the risk assessment at FEMP) assume that the intake distributions included in the analysis are independent. For example, it was assumed that the amount of water and the amount of milk ingested are independent, although this is probably not so. The summary statistics reported for the USDA database do not include these potentially important correlations, nor is there sufficient published information that can be used to estimate the correlations accurately.

There is a specific need for the reanalysis of the data collected in the USDA 1977-1978 survey to provide the summary statistics and correlations necessary to improve risk assessment at USDOE facilities.

\section{Effect of Food Processing}

Ingestion of focd, animal and vegetable, is an important pathway for the uptake of contaminants, both chemical and radioactive. Food processing may significantly affect the concentrations of contaminants found in or on food stuffs. For example, washing may decrease the amount of contaminant adhering to the surface of vegetables as a result of atmospheric deposition. Processing (e.g.. salting) and cooking may alter the concentrations of contaminants in foodstuffs in ways that seriously affect the outcome of a risk assessment.

Unfortunately, little data are readily available to describe the effects of processing and cooking on contaminant concentrations in food. In the risk assessments for tritium and cesium discharged to surface waters at the SRS, we were forced to assume that cooking did 
not change the concentrations of contaminants in fresh fish caught downstream of the facility. Such an assumption may have produced an overestimate of the exposure and risk, at SRS, associated with the ingestion of contaminants in fish. For example, tritiated water that is taken up by fish from Savannah River water is distributed in the body water compartments of the fish. This body water and its associated tritiated water are expected to be removed, to varying degrees, from the diet by cooking, baking and frying. Better data describing the effects of processing and cooking on conlaminanis in food are needed to improve risk assessments at USDOE facilities.

\section{Background Concentrations in the Environment}

In a realistic risk assessment, it is essential to distinguish and estimate the concentrations of contaminants associated with both releases from the facility and those from other sources (background). Variability and uncertainty in background concentrations must be accounted for. The importance of this information was highlighted in the risk assessments for the SRS, FEMP and NTS:

(1) Contaminant release from a site may be a major fraction or may predominate the exposure to and resulting risk from that contaminant (e.g., tritium release to the Savannah River from the Savannah River Site);

(2) Contaminant release from a site may be inconsequential in the presence of high background concentrations (e.g., radon exposures near the Fernald Environmental Management Project); or

(3) Release of a toxic contaminant from a site may be only a minor fracuion of the total exposure to that contaminant, but its contrioution may be sufficient to bring the total exposure to a level that exceeds the threshold level for toxic effects.

We also need to have an understanding of historical trends in background levels of concentration, because risk assessments for USDOE sites are largely predictive. Thus, it is important to understand both natural and anthropogenic contributions to background concenurations of contaminants (e.g., uranium in ground water).

In the pilot study, estimating background concentrations of contaminants in environmental media was often uifficult. For many USDOE sites, data describing the background concentrations of contaminants in air, soil and water are available in Environmental Monitoring repors and other sources, but such information is often not adequate to distinguish natural background concentrations from concentrations in environmental media associated with historical operations at the faciilities. Regional background data are also needed to improve the quality of the risk assessment for each USDOE site, especially when data from a site-specific locale are insufficient.

\section{Background Concentrations in Food}

Only limited data are readily available to describe the concentrations of major contaminants in food. For example, in the risk assessment for uranium in ground water, at the FEMP, the assumed concentration of uranium in food not grown locally was derived from a USEPA analysis of three market basket surveys performed in New York, Chicago and San Francisco. These data are particularly important for the assessment of toxic chemicals when intake from sources other than those associated with the site may bring the total exposure to a level exceeding the toxic threshold. 


\section{Breathing rates}

Because inhalation was the primary exposure pathway to Pu derived from contaminated soils at the NTS, it was important to use realistic inhalation rates for quantifying intake of airborne Pu. We calculated age-dependent breathing rates that were metabolically consistent with the energy expenditures required by different patterns of at:ivity. These breathing rates were adjusted to account for breathing patterns for indoor an' outdoor environments where airborne concentrations of Pu would be different. This aijustment yielded significantly lower inhalation exposures than exposures estimated by using USEPA's default breathing rate of $20 \mathrm{~m}^{3} / \mathrm{d}$.

\subsection{Dose-response Relationships}

Dose-response relationships are major sources of uncerainty in risk assessment. especially when there are assumptions of no thresholds (e.g., carcinogenicity). The shapes of the dose-response curves are subject to bioiogical variability (i.e., individual, age, sex, and physical condition), as well as from uncertain formulation of the relationships per se. The dose from a specific contaminant may be influenced by the chemical (e.g., valence) or physical state (liquid or gas) of the contaminant at and after exposure. These considerations can influence rates of uptake from the gut (e.g., the assessment of uranium at the FEMP), dermal uptake, and uptake from inhalation. Transpor to and retention in target tissues may also be influenced by physico-chemical properties. Therefore, there is a need for a better understanding of the pharmacokinetics of major pollutants.

The USEPA's toxicity and carcinogenicity (slope) factors are near-maximum values based upor: conservative assumptions. Justification for doing this is to protect public health by setting a safety margin for each contaminant. This serves a risk management objective rather than the needs of risk assessment. Use of these factors as single values is prevalent in risk assessment because of their availability, and their derivation and acceptance by regulatory agencies. These factors may not be the most suitable values or the best representation of dose-response relationships. There is a need to develop probabilistic approaches that do not incorporate safety factors, or worst-case or conservative assumptions. As demonstrated in the three site assessments that comprise the pilot study, newer information can be used to express dose-response relationships, health risks, and their respective associated uncertainties in a probabilistic manner.

The USEPA's carcinogenicity factors for chemicals and radionuclides are based upon lifetime exposures $(70 \mathrm{yr})$ to these agents. However, human exposures to contaminants from a speciric source vary both in rate and duration. The assessments for the SRS and the FEMP have demonstrated that lifetime carcinogenic risks can be expressed for varying periods and levels of exposure. There is a need for the development of risk factors that allow for less than lifetime exposure for both chemical and radioaccive carcinogens commonly found at USDOE facilities.

The most common approach to the assessment of toxicity effects involves use of the USEPA Reference Dose (RfD) value, which incorporates safety factors of 10 to 1000 . By setting a safety margin, this procedure really serves the risk management need to protect public healith rather than the need of risk assessment to estimate the likelihood of effects accurately. These values are based on No Observed Adverse Effect Levels (NOAEL) or Lowest Observed Adverse Effect Levels (LOAEL), and do not incorporate uncertainties in pharmacokinetic parameters or natural variations in populations. 
In the risk assessment for uranium in ground water, at the FEMP, a threshold distribution for effects of uranium in the kidney was developed, based on a pharmacokinetic model; the probability of a toxic effect was defined as the probability of kidney uranium concentration exceeding this threshold. This approach explicitly considers uncertainty, and does not depend on safety factors that are judgmentally derived and applied. Thus, for toxic chemicals commonly encountered at USDOE facilities, there is a need for the development of pharmacokinetic models that explicitly include uncerainty and avoid the use of safety factors.

\section{SPECIFIC RESEARCH RECOMMENDAMONS}

Major lessons learned from the pilot study suggest the short-term research projects presented below. These projects will directly and immediately improve risk assessments at USDOE facilities. Many of these projects will be addressed in planned additional work:

(1) to identify major sources of uncertainty in risk assessments at USDOE facilities;

(2) to determine qualitatively or quantitatively the relative contributions of these sources to the overall uncertainty of risk assessments at USDOE facilities; and

(3) to reduce these uncertainties.

\subsection{Risk Assessment Methodology: Distributions for Monte Carlo Simulation}

The pilot study demonstrated the usefulness and applicability of the probabilistic approach to risk assessment. A realistic and probabilistic approach uses the range of possible values for parameters and variables, rather than relying on single values. When appropriate, the risk assessments use distributions of values rather than single estimates for probabilistic analyses of risk, and allow estimates of the uncertainties associated with risk estimates. This approach to risk assessment and uncertainty analysis is now widely accepted as standard in the field. A number of pitfalls and problems were identified in the application of the probabilistic approach in the pilot study, either from published parameter distributions or by deriving the distributions from available data

With the development of specialized software for Monte Carlo simulation, such as @ RISK, CRYSTAL BALL and DEMOS, it is now easy to conduct an enormously complex simulation with only limited knowledge of the basic requirements of the method. As we saw in the early days of software for high-powered regression analysis and other statistical methods, ease of use can lead to abuse, and we are starting to find complex Monte Carlo simulations that contain a broad range of unintended errors and biases that arise from a lack of understanding of how the method works and the implications of apparently simple decisions.

There is a need for information on how to select or create distributions having the necessary characteristics for particular applications, what to do in the absence of highquality information, and what are the implications of incorrect decisions or simplifying assumptions about distributions (e.g., use of parameters that are assumed to be independent, when they are really correlated). Our approach to these problems will be to propose a set of guidelines for choosing assumptions about distributions, and the sensitivity analyses required to test the choices. 


\subsection{Estimation of Risk Reduction}

Most of the effort expended in health risk assessments for USDOE facilities focuses on the current baseline case before any remediation. In deciding to remediate a specific problem, in choosing between remediation options, in identifying acceptable residual contamination levels, and in prioritizing sites for expending limited cleanup resources. USDOE must also consider the amount of risk reduction that will be achieved by specific remedies. An assessment of the risk reduction achieved by a specific remedy should consider the residual risk to current and potential offsite populations, as well as the occupational risks associated with construction, contaminant removal. and transportation. Although the results should show the degree of benefit to be obtained from remedial action. they may show that the remedy actually increases health risks because of occupational exposures to contaminants, accidental exposures to the general public during transportation of contaminants, and the direct effects of accidents per se on workers and the public.

The importance of estimating the risk reduction associated with specific remedies was raised in several of the pilot study assessments. For example, the risk assessment for radon releases from the K-65 silos, at the FEMP, found relatively high risks for fenceline residents. Interim action taken in 1992 to cover the residue in the silos with bentonite is expected to have reduced the emissions and associated risks significandy. The linal remedy is expected to involve complete removal of the residue in the silos. an action that may increase risk due to occupational exposures and transportation fatalities. The risk related to the final remedy should be quantified for use in estimating the actual level of health risk reduction to be achieved.

Estimates of risk reduction are seldom treated with the same analytical detail as the baseline case; usually because models to describe the effects of remediation are not readily available or because the basic assumptions and data concerning emissions and human exposures were not adequately developed. There is a need for development of data, assumptions, and methods to assess the risk reductions (including the additional occupational risks) associated with the remedies likely to be selected for USDOE facilities. These problems will be addressed for courses of proposed remedial actions. in future risk assessments at specific USDOE facilities.

\subsection{Analysis of USDA Database}

Food is expected to be an important exposure pathway for intake of contaminants associated with releases from USDOE facilities to the environment. The USDA database (USDA, 1984, 1989) should be reanalyzed to provide all the information necessary to improve risk assessment at USDOE facilities. This includes descriptive statistics, distributions, and correlations for important parameters that are not independent (see section 4.5). After liaison with the USDA, the database should be accessible by way of standard computer communications that allow the tansmission and downloading of raw data for appropriate analyses. These analyses will be devoted to appropriate grouping by region, age structure of the population, and purchased or home-grown foods. The analyses will be performed with readily available microcomputer software.

\subsection{Effects of Food Processing on Contaminant Levels}

Little data are readily available to describe the effects of processing and cooking on contaminant concentrations in food. Better information is needed specifically about the effects of processing and cooking on important contaminants at USDOE facilities. In the 
risk assessments for tritium and cesium discharged to surface waters at the Savannah River Site, we were forced to assume that cooking did not change the concentrations of contaminants in fresh fish caught downstream of the facility. Such an assumption may have yielded an overestimate of the exposure and risk associated with the ingestion of contaminants in fish.

The US Food and Drug Administration (FDA) has been measuring chemical and radioactive contaminants in prepared, rather than raw, foods for over thirty years (USEPA. 1992b) in an ongoing Total Diet Study (= Market Basket Survey) of the US population. This survey is conducted for 234 (265 since 1991) food items in each of four geographical regions (East, West, South, and Central). Analytical procedures in the Total Diet Study permit measurements at levels 5 to 10 times lower than measurements used in other FDA regulatory programs because food preparation may reduce levels of chemical residues (USEPA, 1992b). The Total Diet Study is grouped according to age and sex of the populations. Informal contact has been established with the FDA, to gain access to the results and data from the Total Diet Study that apply to assessments of specific USDOE facilities. Where necessary, this information will be treated similarly to that obtained from the FDA (see section 5.3).

\subsection{Background Food and Environmental Concentrations}

In a realistic risk assessment, it is essential to estimate the concentrations of contaminants associated with both releases from the facility and those from other sources (background). There is a need for a compilation of data available in the literature and in databases, for information on background concentrations of contaminants, in food and in environmental media. The importance of this information was highlighted in the risk assessments for the SRS and the FEMP.

In the pilot study, estimating background concentrations of contaminants in food and environmental media was often difficult. Only limited data were readily available to describe the concentrations of major contaminants in food. In the risk assessment for uranium in ground water, at the FEMP, for example, the assumed concentration of uranium in food not grown locally was derived from a USEPA analysis of three market basket surveys performed in New York. Chicago and San Francisco.

For many USDOE sites, data describing the background concentrations of contaminants in air, soil and water are available in Environmental Monitoring reports and other sources. Such information is of ten not adequate to distinguish between natiral background concentrations and concentrations in environmental media associated with historical operations at the facilities. Therefore, regional background data are needed to improve the quality of the risk assessment for each USDOE site, especially when data from a site-specific locale are insufficient. The Total Diet Study by the FDA should be useful for establishing regional background levels of contaminants in food, as described above (Section 5.4). In addition, the USEPA (1992b) recently published an inventory of federally sponsored exposure-related data systems. An example of these systems is the Environmental Radiation Ambient Monitoring System, sponsored by the Office of Radiation Programs of the USEPA. Additional appropriate agencies will be identified and contacted for information relevant to risk assessments at specific USDOE facilities, as described above (Sections 5-3 and 5-4). 


\subsection{Method for Handling Exposure to Ground Water Plumes}

The spatial location of a potential human receptor is a critical decision in a risk assessment. Groundwater contamination creates a plume that varies over space and time. Most risk assessments place the individual human receptor directly in the path of the developing plume, and assume that the highest concentration (measured or predicted) represents that receptor's lifetime exposure. This commonly used approach overestimates exposures (and risks) because:

(1) future receptors are not likely to be located exactly along the plume centerline; and

(2) the true concentration at a given receptor will rise and then fall as the plume passes under it.

In the risk assessment for uranium contamination in ground water, at the FEMP, an attempt was made to treat receptors more realistically. At the FEMP, groundwater uranium concentrations over a 70-year lifetime were predicted (using a calibrated groundwater transport model) for each grid cell ( $125 \times 125 \mathrm{feet})$ of the rnodel domain south of the facility. Each cell was assumed to represent a potential future well. The probability of a future well location exceeding a particular level of individual lifetime cancer risk (i.e.. probability of locating a well with risk greater than $1 \times 10^{-6}$ ) and the probability of a future well exceeding the toxic threshold for kidney effects were estimated.

Future tasks will improve on these approaches by accounting for terrain and other factors that might affect the location of future wells. Site- and region-specific data will be gathered for analysis, including use of computerized Graphical Information Systems (GIS), to construct appropriately complex uransport models. Hydrogeologic and demographic surveys (and projections) will be obtained from local. state, and federal sources, as well as private utilities. Partitioning of contaminants among geological materials during transport, and physico-chemical effects of the media on the contaminants will also be evaluated and quantified (e.g., incorporation of $\mathrm{K}_{d} \mathrm{~s}$ into models used at the NTS). The potential uses of ground water for various land-use scenarios will be assessed. The assessments will include considerations of the influence of potential population growth, and the amount of water use an aquifer can suppor The approach may also be applicable to assessment of the risk associated with spatially distributed sources of soil contamination (e.g., plutonium in soil at the NTS), and this application will be investigated further.

\subsection{Less Than Lifetime Exposure to Carcinogens}

Most releases from USDOE facilities produce environmental concentrations in air, ground water or surface water that vary over time at a single location. Corresponding exposures to human receptors will also vary over time. However, most risk assessments performed at USDOE facilities assume a lifetime exposure to the highest measured for predicted) concentration in the environmental media of concern. Published risk factors and slope factors for carcinogens, both radiologic and nonradiologic, assume lifetime exposure. Assessments are performed this way primarily for risk management purposes (puiposeful overestimate to ensure protection of public health) rather than for accurate estimation of risks. The common application of the ICRP ALI (Allowable Limits on Intake) values, developed for 50-year occupational exposures, yields doses committed up to 140 years, for contaminants with long biological half-lives. 
In the assessment for uranium cancer risk at the FEMP, a more realistic assessment was performed by using the ICRP ALI values, and the retention function for uranium, to estimate the effective dose delivered over a lifetime for a unit intake (1 Bq*year ${ }^{-1}$ ) in each year of life. This allows calculation of the effective dose and associated risk for a varying intake starting in a given year of life. Similarly, in the assessment at the Savannah River Site, the dose from ${ }^{137} \mathrm{Cs}$ was calculated from the ICRP 30 retention function, modified for chronic annual intake.

Risk factors should be derived for important carcinogens at USDOE facilities, to support risk assessments for less than lifetime exposures. In assessing specific contaminants at USDOE sites, we will continue to analyze published risk factors and ICRP ALI values, and conver these factors and values into effective lifetime doses per unit intake (e.g., per Bq*year ${ }^{-1}$ or per $\mathrm{mg}^{*}$ year ${ }^{-1}$ ). These dose-per-unit-intake values will account for pharmacokinetics and biological half lives of the contaminants. Total doses can then be calculated for actual number of years exposed, instead of assuming lifetime exposures.

\subsection{Improvement of Biotransfer Factors}

Many of the health risk assessments at USDOE facilities include pathways through edible fish, meat, milk, fruits and vegetables to humans. Unfortunately, little data are available in the literature to support estimation of biotransfer factors for contaminants of concern, at USDOE facilities. The three pilot study risk assessments relied on the limited data currently available in the literature.

For USDOE facilities, estimates of biotransfer of contaminants to the food chain should be improved. The approach we propose is to derive an index for major contaminants of concern at USDOE facilities. This index will be chemical specific and will address the empirical relationship between chemical structure, solubility, uptake and metabolism. Unlike other estimators of biotransfer factors (e.g., octanol-water partitioning), this procedure may be a better predictor of the susceptibility of a chemical to metabolic breakdown, and a more useful tool for determining the potential transfer of a chemical between different biological comparments. This approach should also be applicable to evaluating the biotransfer of contaminants in mixed waste at USDOE facilities.

\subsection{Factors Affecting Frequency and Duration of Exposure}

The highest risks for residual $P u$ at the NTS were calculated for the farm scenario. An important factor affecting the predicted risk was the duration of residence at a given home for individuals living in rural areas. Additional data are needed to determine the time farmers spend outdoors at locations adjacent to or near their homes. This is important because outdoor inhalation of resuspended $\mathrm{Pu}$ is expected to yield the highest exposures.

Mobility of people changes as a function of age, and hence cumulative exposures to a contaminant, and related doses and risks. at a given site will change as a function of age. More research is needed to quantify the relationship between age and mobility.

These problems will be addressed by analyses of data bases, such as the Social, Environmental, Demographic Information System. sponsored by the USDOE and the US Department of Labor (USEPA, 1992b). 


\subsection{Risk Characterization for Plutonium and Noble Gases}

More research is needed to quantify the risk of lung cancer for alpha-emitting nuclides, including Pu. The relationship between smoking and exposure to radon appears to be a critical uncertainty in the derivation of existing risk factors for radon and its progeny.

Additionally, risk from ingestion of radioactive noble gases in ground water could not be addressed adequately because dose-conversion factors for ingestion of such radioactive elements are not defined. Therefore, deriving dose-conversion factors for radioactive noble gases that could exist in ground water, at the time of consumption by humans, would be useful for purposes of a complete and thorough risk characterization.

Surveys of published literature will be performed for appropriate data and new information. These data will be analyzed to define dose- and risk-conversion factors.

\section{SUMMARY AND CONCLUSIONS}

Realistic risk assessments were completed in a pilot study of three USDOE sites. The pilot study assessments were used in this document to identify and guide research to:

(1) eliminate gaps in data; and

(2) address methods needed for risk assessment at USDOE facilities.

Specific recommendations for short-tenn research that will improve risk estimates at USDOE facilities markedly include:

(1) selection of distributions of parameters for Monte Carlo simulations;

(2) assessments of risk reduction associated with specific remediation approaches;

(3) Reanalysis of the 1984 and 1989 USDA data bases for use in risk assessment;

(4) effects of processing and cooking on contaminant levels in foods;

(5) background concentrations of contarninants in the environment and foods associated with USDOE facilities;

(6) methods for handling groundwater plumes associated with DOE facilities;

(7) methods for analyzing risks from less than lifetime exposures to carcinogens;

(8) improved estimates of biotransfer factors;

(9) determination of factors that affect frequency and duration of exposure; and

(10) risk characterization for plutonium and noble gasses.

We specifically recommend the initiation of a systematic approach to identify, prioritize, and reduce sources of uncertainty in risk assessments at DOE facilities. 


\section{REFERENCES}

Blackwood, LG., 1990, The lognormal distribution, environmental data, and radiological monitoring, Environ. Monitor. Assess. 21: 193-210.

Burmaster, D.E., and R.H. Harris, 1993, Perspective: the Magnitude of compounding conservatisms in Superfund risk assessments, Risk Anal. 13: 131-134.

Callahan, B., and P.A. McCaw, 1993. Risk assessment alleviates environmental liabilities, Hydrocarbon Processing 72: 61-64.

Daniels, J.I., R. Andricevic, L.R. Anspaugh, and R.L. Jacobson, 1993, "Risk-Based Screening Analysis of Ground Water Contaminated by Radionuclides Introduced at the Nevada Test Site (NTS)," in Pilot Study Risk Assessment for Selected Problems at the Nevada Test Site (NTS), J.I. Daniels, Ed., Lawrence Livermore National Laboratory, Livermore, CA, UCRL-LR-113891, pp. 69-97.

Ershow, A.G., and K.P. Cantor, 1989, Total W.ter and Tapwater Intake in the United States: Population-Based Estimates of Quantities and Sources, Life Sciences Research Office, Federation of American Societies for Experimental Biology, Rockville, MD.

Hamilton, L.D., S. Holtzman, A. Meinhold, S.C. Morris, R. Pardi, C. Sun, J.I. Daniels, D. Layton, T.E. McKone and T. Straume, 1993a, Pilot Study Risk Assessment for Selected Problems at the Savannah River Site (SRS), Brookhaven National Laboratory, Upton, N.Y., BNL-48776.

Hamilton, L.D., A. Meinhold, S.L. Baxter, S. Holtzman, S.C. Morris, R. Pardi, M.D. Rowe and C. Sun, 1993b, Pilot Study Risk Assessment for Selected Problems at the Fernald Environmental Management Project (FEMP). Brookhaven National Laboratory, Upton, N.Y., BNL-48777.

ICRP, 1979, Limits for Intakes of Radionuclides by Workers, International Commission on Radiological Protection, ICRP Publication 30, Part 1. Annals of the ICRP Committee 2, No. 3/4, Pergamon Press, Oxford.

ICRP, 1991 a, 1990 Recommendations of the International Commission on Radiological Protection, Publication 60, Annals of the ICRP. Pergamon Press. Oxford.

ICRP, 199 lb, Annual Limits on Intake of Radionuclides by Workers Based on the 1990 Recommendations, Publication 61, Annals of the ICRP, Pergamon Press, Oxford.

Layton, D.W., L.R. Anspaugh, K.T. Bogen, and T. Straume, 1993, "Risk Assessment of Soil-Based Exposures to Plutonium at Experimental Sites Located on the Nevada Test Site and Adjoining Areas," in Pilot Study Risk Assessment for Selected Problems at the Nevada Test Site (NTS), J.I. Daniels, Ed., Lawrence Livermore National Laboratory, Livermore, CA. UCRL-LR-113891, pp. 19-67.

Paustenbach, D.J., D.M. Meyer, P.J. Sheenan and V. Lau, 1991, An Assessment and Quantitative Uncertainty Analysis of the Health Risks of Workers Exposed to Chromium-Contaminated Soils, Toxicol. Indust. Health 7:159-196.

Roseberry, A.M., and D.E. Burmaster, 1992, Lognormal distributions for water intake by children and adults, Risk Analysis 12: 99-104.

Till, J.E., and H.R. Meyer, (eds.) 1983, Radiological Assessment: A Texabook on Environmental Dose Analysis, NUREG/CR-3332, U.S. Nuclear Regulatory Commission, Washington, D.C., OR:

USDA, 1984, Nutrient Intakes: Individuals in 48 States, Years 1977-1978, Nationwide Food Consumption Survey 1977-1978, Report No. I-2. Human Nutrition Information Service, United States Department of Agriculture, Hyattsville, MD.

USDA, 1989, Food and Nutrient Intakes of Individuals in One Day in the United States, U.S. Department of Agriculture, Spring 1977, Nationwide Food Consumption Survey 1977-1978, Preliminary Report No. 2. 
USEPA, 1989, Risk Assessment Guidance for Superfund, Vol. 1, Human Health Evaluation Manual (Part A), Iterim Final, EPAJ540/1-89/002, Office of Emergency and Remedial Response, United States Environmental Protection Agency, Washington, D.C.

USEPA, 1991, Health Effects Assessment Summary Tables, Annual FY-1991, OERR 9200.6-303 (91-1), United States Environmental Protection Agency, Washington, D.C.

USEPA, 1992a, Guidelines for Exposure Assessment; Notice. Fed. Regist. 57: 2288822937.

USEPA, 1992b, Inventory of Exposure-Related Data Systems Sponsored By Federal Agencies, EPA/600/R-92/078, Prepared by Eastem Research Group, Inc., Lexington, MA.

USNRC, 1977, Regulatory Guide 1.109: Calculation of Annual Doses to Man from Routine Releases of Reactor Efluents for the Purpose of Evaluating Compliance with 10CFR Part 50, Appendix I, U.S. Nuclear Regulatory Commission, Washington, D.C. 